\title{
Granite Mining at Eluogwu Land, Amata-Ishiagu By Crush Stones Industries Ltd 1993 -2008.
}

\author{
JOSEPH C. CHUKWU (Ph.D) (READER) \\ DEPARTMENT OF HISTORY AND INTERNATIONAL RELATIONS,
}

ABIA STATE UNIVERSITY, UTURU.

E-mail: joejah22@yahoo.com

\begin{abstract}
Most of the granite mining activities that took place at Amata village, Ishiagu were within parcels of land belonging to a particular kindred called Umuelema. Individual and private company miners at various times operated there after reaching agreements with the members of the Umuelema family. Conversely, Eluogwu land was communally owned by the entire Amata village. Crush Stones Industries Ltd happened to be the only company that had carried out mining operations on this communal land. Conditions for granting permission to the company to operate there were clearly set out in the land-owner/Tenant lease agreements. The company made use of paid labourers and some modern mining equipment in the course of its mining operations. The company ultimately benefited from the enterprise, while the land owners apparently lost out with very little remuneration from the company for their resources tapped and pollutions suffered.
\end{abstract}

Keywords: GRANITE MINING, NIGERIA

DOI: $10.7176 / \mathrm{HRL} / 53-04$

Publication date: April $30^{\text {th }} 2021$

\subsection{INTRODUCTION}

Amata village is located at the Western part of Ishiagu, Ivo Local Government Area of Ebonyi state. It shares a common boarder with Lokpa-Ukwu in the present Umunneochi Local Government Area of Abia State. Amata Lands generally are stone-ridden and is therefore not very good for agriculture.

Until the post Nigeria civil war era, from the 1970s, no mining operations of any kind took place there. The reason for this probably was as a result of its location far inside the interior where the minimum influence of the Colonial Administration hardly penetrated. So, throughout the Colonial era and few years of port Colonial period before the Nigeria civil war ensued, practically nothing was known about the area let alone people and companies scouting for the resources of the land.

Colonial administration was the premier stimulus that introduced stone-mining exercise as major economic enterprise in Igboland generally. This translated to realism the dreams of constructing good and solid roads, residential and office quarters, air-ports, bridges and culverts, among others.

However, by the end of the Nigeria's civil war in 1970, the various governments of the federation, namely Federal, State and Local Governments embarked on various projects of reconstruction and rehabilitation. Igboland which was a major theatre of the war received attention of these governments to reconstruct and rebuild a wide range of damaged and devastated structures across Igboland. To achieve this feat, the material resources (raw material) came to be of paramount interest. At this time, the interior location of Amata ceased to be a 
barrier. Mean while a network of roads had linked up all the villages, of Ishiagu including Amata village. Individual and private companies found their ways into parts of Umuelema family lands for purposes of mining.

By 1993, the company, Crush Stones Industries, explored the area and settled at the Eluogwu land which was owned by the entire village community of Amata. It entered into land lease agreement with the village community. The company undertook mining and quarrying activities there. Some sons of Ishiagu too, were under the employ of the company. ${ }^{1}$

However, the company gained appreciably at the expense of the land owners. In the essay, efforts are made to discuss the land lease agreements between Amata village leaders and the company, labour organization types of products produced by the company and the general impact of the mining on the community at large.

\subsection{ADVENT OF CRUSH STONES INDUSTRIES AT AMATA}

The coming of the Crush Stones Industries into Amata village, Ishiagu, for the purposes of granite mining business must have been an outcome of a number of factors. First was the knowledge of the presence of igneous rock out crops in the area.

The area and infact Ishiagu community at large would appear to be part of the ridge of highlands running from Nsukka through Udi and Okigwe, referred to by students of physical geography as Nsukka-Okigwe cuesta $^{2}$. This included places such as Nsukka, Awgu, Udi Lokpaukwu, Okigwe, Lekwesi and Ishiagu communities.

In addition to the above, granite mining had become an important economic activity in parts of Umuelema family lands, Amata village, Ishiagu, since the end of the Nigeria's civil war in 1970. Actually umuelema kindred was part and parcel of Amata village, but the said land was specifically under the control and supervision of Umuelema kindred. Various individuals and private company miners had been in this enterprise since the end of the Nigeria's civil war in 1970. Among private miners there were Aro Nweke and Uche Nwajah among others. The private company miners that operated there were chief Onyeso Nwachukwu mining company, Ezekiel Ehibudu mining co. Stephen Ofomata co., and Consolidated Construction Company (CCC) Nig. Ltd ${ }^{3}$. Another major factor that encouraged the Crush Stones Industries to settle at Eluogwu for granite mining was availability of a net-work of access roads linking the site to the major roads in Ishiagu, Lokopaukwu, Enugu-Port Harcourt express way and a host of other access roads ${ }^{4}$. These road networks encouraged uninhibited movements of the company's material products to various destinations. The network of roads also guaranteed free access of customers from virtually every part of the Nigerian society to the site for business transactions ${ }^{5}$.

There was also the basic factor of peaceful co-existence among the landowners and their neighbour. This was devoid of raniour and violence. The people of Amata village were peace loving; they never settled for war with their customers and clients over the decades. Their customers operated freely, unharassed by the Amata 
people as long as they conducted themselves within the limits of their mandates and codes of the societal laws and culture. ${ }^{6}$

These and some other factors were attractive enough for any prospective miner, be it an individual miner, private company, or a limited liability company. So in 1993, Crush Stones Industries landed at Amata village Ishiagu to consult with the elders of the community. Prior to this time there had been foreign companies that had established at parts of ishiagu community for granite mining purposes. These were the Monier Construction company M.C.C and Crushed Rock Industries at Amokwe rocky hills. These were of great economic benefits to the communities the companies operated. These village communities included. Amokwe, Okue, Ogwor and Ngwogwo. So, the coming of the Crush Stones Industries in Amata village was indeed a welcome development. The Amata village elders and the Crush Stones management sued for co-operation and symbiotic relationship in the business. The nature and character of the relationship had to be clearly defined and spelt out in the land lease agreement between the land owners and the Crush Stones Industries ${ }^{7}$

\subsection{AN AGREEMENT BETWEEN AMATA COMMUNITY AND CRUSH STONES INDUSTRIES LTD}

This memorandum of agreement for lease is made this $9^{\text {th }}$ day of November, 1993 between (1) Mr. S.I. Chukwu, (2) J. C. Okochi (3) Joseph Ovia (4) Mr. D.O. Chukwu (5) Mr. Sunday Elema (6) Mr. Igwe Okoro Onu (7) Mr. Aja Okochi (8) Mr. Sylvester Aroh (9) Mr. Alexander Ajah (10) Chief Innocent Ajah and (11) Chief Pius Enyi (for themselves and as representatives of members of Amata village community, Ishiagu, Ohaozara LGA, Abia State of Nigeria (hereinafter called "The Lessors which expression shall where the context so admits include their successors in title and assigns) on the one part, and Crush Stones Industries Ltd, a company incorporated in Nigeria and having its registered office at kilometer 20, Port Harcourt Expressway, Oyibo, in Oyibo Local Government Area of Rivers State of Nigeria (hereinafter called "The Lessee" which expression shall where the context so admits include its successors in title and assigns) of the other part.

\section{WHERE AS}

1) The members of Amata Community are owners in possession of the parcel of land known as, and called "Elu-ogwu" situate at Amata in Ishiagu, Ohaozara LGA of Abia State of Nigeria measuring approximately 19.5278 hectares, shown and delineated on perimeter survey plan attached hereto and bounded by temporary peg numbers $\mathrm{CB}$ to $\mathrm{CB}_{14}$ and another parcel of land measuring 16.757 hectares and bounded by peg numbers L8 to CBS.

2) The Lessee is desirous to acquire a quarry lease in respect of the above named parcel of land together with stones there in (hereinafter called "The Quarry") and the Lessors have agreed to demise the said quarry into the Lessee for a term of 50 (fifty) years with the authority and consent of the principal members of Amata Community aforesaid.

The lessee has obtained Quarrying lease No. 4329 and lease No. 4332 formerly lease No. 1286 of fougerolle Nig. Ltd, from the Federal Ministry of mines and power, Mines Department, Enugu, which licenses cover the quarrying Area of the lease. 


\section{IT IS HEREBY AGREED AS FOLLOWS:}

1) That the provisions of Quarry Decree 1959 and Quarry Regulations, 1969, shall form integral part of this agreement.

a. Under the decree, quarriable minerals of which stone is one, belong to the Federal Government to whom the Quarryer will pay royalties.

b. Any person conducting quarrying operation shall pay the owner or occupier of private land or the occupier of land held under any lease granted by the government of the federation or the subject of a right of occupancy, such sums as may be fair and reasonable compensation for any disturbances of the surface rights of such owner or occupiers.

c. The lessee shall pay compensation to the owners of any crops, economic trees, buildings or works damaged or removed or destroyed by the lessee.

d. Reasonable compensation payable to the said community will be based on (b) and (C) above that is loss of right of farmland and loss of economic trees which compensation has been agreed upon by the parities hereto in paragraph 5 and 6 hereunder.

2) That the lessee shall pay the lessors annual rent of the sum of (N100,000.00) one hundred thousand naira, commencing from the $9^{\text {th }}$ day of November, 1993 subject to review after every five (5) years from the date of execution hereof.

3) The lessee shall give to the lessors annual Christmas presents of one cow, 100 tubers of yam, 20 cartons of beer, 20 crates of minerals, four heads of tobacco and potash.

4) The lessee shall pay to the lessors, the sum of N50,000.00 per annum during the currency of this agreement for existing economic crops and or plants thereon and for loss of farmland or rights to farm on the said land.

5) The lessee shall pay to the lessor the sum of $(\mathrm{N} 25,000)$ per annum for disturbance allowances.

6) The lessee shall make motorable, Amata road, from Girls Secondary School, Ishiagu to lessee's quarry site at Amata, and the lessee shall carryout this undertaking after (12) twelve months from the date of commencement of production.

7) The lessee shall employ and train three indigenes of Amata Community as technicians in its company. This agreement was signed by the above named representatives of Amata Community and Crush Stones Industries Ltd. ${ }^{10}$

Crush Stones would appear to be honest. It tried as much as possible to operate within the ambit of the agreement. There was no crisis whatsoever. Both parties were satisfied with the role played by each other in operating the terms of the agreement. At the end of the five year duration of the agreement, it was renewed revised in 1998. We shall therefore have a look at the revised agreement.

\subsection{RENEWED AGREEMENT BETWEEN AMATA COMMUNITY, ISHIAGU AND CRUSH STONES INDUSTRIES LTD, 1998}

The 1993 agreement was revised/reviewed in 1998, after five years of the company's operation on the land. All the contents of the 1993 agreement were replicated, and new items, that is items numbers eight and nine were added ${ }^{11}$. Item number (8) eight states that, the lessee shall award two secondary school scholarships 
(of tuition fees only and (N20,000.00) twenty thousand naira annually for university scholarship award to Amata indigenes. Number 9 states that, the lessee shall give to the lessors 75 tons of No.3 chippings every year ${ }^{12}$. The 1998 agreement was signed by (1) M.C.U. Onu (2) S.I. Chukwu (3) P.S. Arum (4) Chief Pius Enyi (5) Chief Orji Okorie (6) Chief Alex Ajah (7) Chief Fabian I. Eze (8) Chief Ajah (9) Uwakwe Ajah (10) Sylvester Aroh (11) Okochi Ukah. (for Amata Community. Ichie Mikel Ezenduka, chairman, Crush Stones Industries Ltd. Signed for Crush Stones industries $\operatorname{Ltd}^{13}$.

The agreement was again renewed in 2004 instead of $2003^{14}$. This was prepared by Louis M. Alozie Esq. \& Co. Equity Chambers, 110 Wetheral Road, Owerri, Imo State.

This agreement witnessed some substantial changes starting from item number (2) two of the first/original agreement. Item number one was unchanged in its contents ${ }^{15}$. The rest were revised and they are as follows:

1) That the lessee shall pay to the lessors annual rent of the sum of five hundred thousand naira for the period of this agreement.

2) The Lessee shall give to the lessors annual Christmas presents of one fat cow, 150 tubers of yams, 30 crates of minerals, 30 cartons of beer, 8 crates of Ngwo, palm wine, one carton of hot drinks (seamans quality), 8 heads of tobacco with potash, and 5 cartons of multina.

3) The lessee shall pay to lessor, the sum of $\mathrm{N} \mathrm{100,000.00} \mathrm{per} \mathrm{annum} \mathrm{during} \mathrm{the} \mathrm{currency} \mathrm{of} \mathrm{this}$ agreement for existing crops and/or plants thereon and for loss of farmland or right to farm on the land.

4) The lessee shall pay to the lessor the sum of N750,000 per annum as disturbance allowance.

5) The lessee shall make motorable with laterite, the road from the lessee's quarry site to Agbalasi and to Girls' Secondary School, Ishiagu in the Lessors' community.

6) The lessee shall train (8) eight indigenes of Amata community as technicians in its company.

7) The lessee shall award tertiary institutions scholarship for indigenes of the lessors community at N100,000.00 per annum.

8) The Lessee shall give the Lessors 100 tons of chippings every year.

9) The lessee shall within the period of the agreement provide 50 concrete poles for the lessors rural electrification project in two installments or 25 poles each.

10) The lessee shall pay a Public Relations Officer to be appointed by the lessors community development union, whose responsibility it shall be to facilitate free flow of information between the parties.

11) By way of recognition, lessee shall pay the under mentioned, allowances/stipends to the following groups in the lessors community.

i. The Executive members of the Amata Community Development ' Union, N150,000.00 per annum.

ii. Traditional Rulers/Eze and Chiefs of Amata Community N 150,000 per annum.

iii. The youths of Amata N 100,000 per annum.

12) The fifty year tenure agreed on the first lease agreement in 1993 remains valid and subsisting from the date of that agreement. The agreement was signed by the above representatives of the Amata Community and Crush Stones Ind. Ltd.

A close look at this agreement would reveal some major weakness on the part of the lessee and lessors.

One of these weaknesses was the failure on the part of the lesses to renew the agreement in 2003 when it was 
due for renewal. No reason was stated for this failure. No informant could give any definite reason for this. Mr. P.S Arum said, "Crush Stones are good people. They don't play tricks. So we received them whenever they came for the agreement"17. The reaction from Mr. Arum would simply conote trust and confidence which the lessors reposed on the lessee probably as a result of the good experiences they had about the company. There is nothing wrong in the lessor reposing such confidence in lessee, but there is every need to insist on correct date. The agreement should bear 2003 and not 2004 as the date the agreement was renewed. There should be reason why the lessee could not present itself for the agreement on the right date. It should even be accompanied with apology to the lessor.

Another weakness of the agreement was on the nature of benefits the lessors demanded from lessee. They were mainly fiscal cash, cow drinks and tobacco. These monies and presents were immediately shared by the representatives of the community. No genuine development project was ever embarked upon by the community leaders, using the money they collected from the company. So one would be right to say that the agreement was not development oriented. The company on its own never embarked on any meaningful development project in favour of the community. This was because the leaders of the community/lessors never insisted on this.

Take for instance, instead of the lessors insisting on tarring their roads, what they demanded for in the agreement was a road, covered with laterite and not even granite chippings produced by the company concerned. Again, in the agreement, instead of the lessors asking for rural electrification of their community by the company, they were asking for mere 50 electric poles. In the case of education, the sum of $(\mathrm{N} 100,000)$ one hundred thousand naira was mapped out for scholarship at tertiary level. But the number of candidates this amount was meant for was not mentioned. Genuine demand should investigate how many people in the community should benefit from the scholarship scheme and how much the company should pay for their tuition, boarden and other requirements of those involved. It was because of these and other lapses on the part of the agreement (which should be a guide in the lessor/lessee relationship) that Amata community Ishiagu still remained incredibly underdeveloped despite a long period of granite mining in the area.

\subsection{METHOD OF OPERATION}

Crush Stones Industries applied highly mechanized methods in its production process. It made use of driller machine capable of penetrating a bed-rock up to a depth of 20 metres before explosion took place ${ }^{18}$. The commonest explosive chemical it applied was dynamite. Before it was applied, alarm was sounded for everybody to clear from the site, so as to avoid any casualty. Because the location of the site was right inside the farmstead, the storms and thundering vibrations of the explosives never affected any building ${ }^{19}$.

At the end of the explosion, earth-moving vehicles were used to lift lumps of granite which were loaded into tipper. The tipper dropped the lumps inside the funnel of a crushing machine, located at a different section of the site ${ }^{20}$. The crusher then crushed the lumps into sizes which passed through their respective outlets and finally dropped on the ground from where they were loaded into tippers that ultimately discharged them at their appropriate locations. 


\subsection{DISTRIBUTION OF PRODUCTS}

From 1993 to 2005, thousands of people as well as construction companies had gone to the Crush Stones site to buy tons of chipping loads. The list is inexhaustible. The table below indicates a sample of this list of customers to Crush Stones Industries:

\begin{tabular}{|c|l|l|}
\hline S/N & CUSTOMER COMPANY & ADDRESS/ DESTINATION \\
\hline 1. & Umezu Construction Company & Awommamma, Imo State \\
\hline 2. & J. D.P Nig. Ltd & Owerri, Imo State \\
\hline 3. & Hardel \& Enic Nig. Ltd & Owerri and Port-Harcourt \\
\hline 4. & T.I.O. Nig. Ltd & Owerri Imo State \\
\hline 5. & O.C.C. Nig. Ltd & Okigwe Imo State \\
\hline 6. & Elite Nig. Ltd & Umuahia, Abia State \\
\hline 7. & Eagle Const. Co. Ltd & Abagana, Anambra State \\
\hline 8. & Pek in Ventures & Onitsha, Anambra State \\
\hline 9. & Enerco Nig Ltd & Owerri \& Nsukka \\
\hline 10. & Hapel Nig. Ltd & Abakaliki \& Onitsha \\
\hline 11. & Raycon Nig. Ltd & Owerri, Imo State \\
\hline 12. & Ponti\&Co. Nig. Ltd & Orlu, Imo State \\
\hline 13. & Predoco Nig. Ltd & Port Harcourt, River State \\
\hline $1 . s 0$ & & \\
\hline
\end{tabular}

Table 1: source: Crush Stones Offices, Amata Ishiagu, 2000-2008

According to an informant, an average of 50,000 tons of sold chippings were evacuated from the Crush Stones site daily, by different haulage vehicles to various destinations where they were used for road construction, building construction, airport projects or any other construction project that required use of chippings ${ }^{24}$. John Ovia was of the view that the company made tremendous profits from the business. Thus he said

Beside on the quantity of chippings sold and evacuated from this site to various destinations, the company would appear to have made a lot of profits from this business. Yet, there is no record of any community development project it had independently undertaken and completed in favour of Ishiagu community. She could not provide good road, pipe-borne water or bore-hole, electricity, health center or even a functional scholarship scheme for the community. ${ }^{52}$ 
The few obligations in the agreement were hardly implemented by the company except under pressure. Even the said obligations were solely and entirely for Amata village community. ${ }^{25}$

\subsection{GENERAL IMPACT OF THE CRUSH STONES MININFG ACTIVITIES ON AMATA VILLAGE, ISHIAGU}

An objective assessment of this issue should consider how the community and company leaders substantially met and satisfied the conditions as stipulated in the land lease agreement. These were supposed to be a good guide to both parties in the task of maintaining mutual relationship between them. Also relevant is how the company handled the delicate issues of environmental pollutions and hazards arising from its mining operations. Of serious importance too, was the manner the company and community leaders resolved some sensitive and delicate issues arising from the youth and women demands even when the issues were not part of the contents of the land lease agreements.

\section{ROLES OF THE COMMUNITY (LEASER) AND COMPANY (LEASEE)}

All through her period of operation at the site, the company had never raised any complaint accusing the community or its leaders of intruding, distracting or interrupting its operations. The area remained intact for the mining activities of the company. ${ }^{26}$ The area in question, Eluogwu, had its natural beacons which served as its boundaries. No one or group of people ever dared to venture into the area either to possess or dispossess any part of the land; it was a communally owned land and any attempt by anyone or group of people to intrude, would be resisted by the entire community. ${ }^{27}$ In other words, the community played well its roles as stipulated in the agreements.

On the part of the company, it played well its roles only as it concerned her economic interests of mining, crushing and selling her products to her customers for profits. ${ }^{28}$ But as far as it concerned the various obligations and responsibilities it owed the community as clearly stipulated in the lease agreements, it performed below expectation. It defaulted abysmally.

As shown above, an average of 50,000 tons of sold chippings were evacuated from the Crush Stones site daily, by different haulage contractors to various destinations where they were used for road construction, building constructions, air-port projects or any other constructions projects that required use of chippings. This was quite tremendous and the accrued profits to the company would appear to be huge too, given the price of chippings per ton, over the period of its operations there. Yet despite the huge profits, there was no record of any community development project it had independently undertaken and completed in favour of Amata village or Ishuagu community either. She would not provide good roads, pipe-borne water, or bore-hole, electricity, health care services (Health center), or even a functional scholarship scheme for the community. The few obligations in the agreement were hardly implemented by the company except under pressure ${ }^{29}$. Even the said obligations were solely and entirely for Amata village community. For instance in the lease agreement, the company was meant to float at least a simple scholarship scheme for few students at the secondary and tertiary institutions. This was 
almost a mirage, due to incessant failures and default by the company to meet the demands. ${ }^{30}$ So, in the end no one could enjoy the full sponsorship of the company to conclude his or her academic career. This was largely due to the lapses on the part of the company to meet its obligations to the community. ${ }^{31}$

On the issue of paying compensation to the community du to environmental pollutions, occasional by its operations, the company was also found seriously wanting. There were various forms of pollutions caused by the operations of the company. These included water pollution which affected the streams, ponds, wells and rivers; air-pollution affected the crops, leaves and animals around (flora and fauna). ${ }^{32}$ This affected the general agricultural outputs of the community at different times. But the company would not pay any compensation to the community for the purpose of alleviating the sufferings encountered by the community due to the volume of pollutions unleashed by the companies mining activities. ${ }^{33}$

Asked why the community failed to act against these lapses or insist on the company fulfilling the terms of the agreement, Mr. Daniel Osi revealed that some elites of the community who ought to enforce compliance on the part of the company sabourtaged the community. They benefitted a lot from the company through special favours, grants and contract award among others..$^{34}$ continuing he said;

You cannot eat your cake and still have it. After fraternizing with the company management, benefiting from them, it was practically impossible for the same people to turn round to accuse the company leadership of non-performance. So, the community with large number of illiterate and poverty ridden population had to live at the mercy of the company throughout the duration of the company's stay and operation in the area. ${ }^{35}$

\section{CONCLUSION}

Mining operations of Crush Stones Industries Ltd in Eluogwu in Amata village Ishagu, lasted for over ten years 1993 - 2009. Its operations were peaceful; it worked under terms contained in the lease agreements between the Amata village community (Leaser) and the company (leases). It made use of modern mining equipments that facilitated its operations and huge outputs. The quality of its products as well as availability of network of roads attracted large number of customers to the company. It made use of skilled and semi-skilled workers from within and outside Ishiagu community.

Unfortunately the progress made in this site was one sided. While the company benefited substantially in the mining operations, the community almost practically lost out. In what appeared to be collusion between the company and some community leaders, the entire community failed to benefit much, leaving the so called community elites to short - change the community. Thus, most of the obligations the company owed the community remained farcical and unfulfilled throughout the period it operated there. This simply meant that while the company was the beneficiary, the community remained to extent the loser. 


\section{NOTES/REFERENCES}

1. Michael Osi, A retired headmaster and community leader, aged 75 years, interviewed at Amata village, Ishiagu on 7 March, 2007.

2. A.E. Afigbo, Ropes of Sand. Studies in Igbo History and Culture Ibadan: university Press Ltd, 1981, P.7.

3. Benedict Nwajah, A retired teacher aged 67 years, interviewed at Amata village, Ishiagu, on $5^{\text {th }}$ March, 2007.

4. Mark Osi, A businessman, aged 65 years, interviews at Amata village on $7^{\text {th }}$ March, 2007.

5. Mark Osi, interview cited above.

6. Ajah Anyim, A successful farmer, aged years, interviewed at Amata village, Ishiagu, on $10^{\text {th }}$ April, 2007.

7. Fidelis Eze, A management staff of the Crush Stones Industries and native of Udi, Enugu state, interviewed at Crush Stones site, Eluogwu-Amata, on $8^{\text {th }}$ March, 2007.

8. An agreement document on land lease between Crush Stones Industries Nig. Ltd and Amata community, Oha-ozara LGA, Abia state dated $9^{\text {th }}$ day of November, 1993.

9. Ibid.

10. Ibid.

11. J.C. Chukwu. "Mining operations in Ishiagu, Lokpa-ukwu, Lekwesi and Uturu communities 1900-2005" (An unpublished Ph.D thesis submitted to Department of history International studies, UNN, Feb. 2010) P. 236.

12. Ibid.

13. Ibid.

14. Renewed Agreement between Amata village community and Crush Stones Industries on land lease 8 November, 2004.

15. J.C. Chukwu, p. 309.

16. John Okoro, staff of the Crush Stone Industries Ltd, aged 56 years interviewed at the Crust Stones site, Eluogwu Site, Amata Ishiagu on 8 March, 2007.

17. P.S. Arum, Amata village community leaders, aged 54 years, interviewed at Amata on 8 March, 2007.

18. Paul Osi, former staff of the Crush Stones Industries, aged 60 years interviewed on 7 March, 2007.

19. Paul Osi, interview cited above.

20. Paul Osi, interview cited above.

21. Paul Osi, interview cited above.

22. Patrick Ude, former staff of Crush Stones Industries Amata Ishiagu (Driver), interviewed at Crush Stones Industries site, Eluogwu, Amata Ishiagu on 10 March, 2007.

23. Table one reflects a list of customer companies that came to the Crush Stones site at Eluogwu Amata to buy and carry tons of chippings to their various destinations. Their respective addresses are also indicated in the table.

24. Simon Uche, senior staff (Transport officer) of Crush Stones Industries interviewed at Crush Stones site Eluogwu Amata on 8 April, 2007, aged 51 years.

25. John Ovia, a business man and Amata community leader aged 52 years, interviewed at Amata play ground Amata on 16 March, 2007. 
26. John Ovia, interview cited above.

27. John Ovia, interview cited above. Mr. Ovia was trying to exonerate the community from any flaws. He felt that Amata community co-operated faithfully with the company, despite the lapses on the part of the company.

28. John Ovia, interview cited above.

29. John Ovia interview cited above.

30. James Ajah, teacher aged 56 years. Supporting the views of Mr. John Ovia. James Ajah was a native of Amata village and as well a community leader by virtue of his educational background. He was of the view that the company performed below expectation.

31. James Ajah, interview cited above.

32. Daniel Osi, a teacher, aged 50 years interviewed at Amata village square on 10 April, 2007.

33. Daniel Osi, interview cited above.

34. Daniel Osi, interview cited above.

35. Daniel Osi, interview cited above. 